\title{
Pile settlement and volume reduction measurement during forced-aeration static composting
}

\author{
Bo Yue ${ }^{\mathrm{a}, \mathrm{b}}$, Tong-Bin Chen ${ }^{\mathrm{a}, *}$, Ding Gao ${ }^{\mathrm{a}}$, Guo-Di Zheng ${ }^{\mathrm{a}}$, Bin Liu ${ }^{\mathrm{a}, \mathrm{b}}$, Duu-Jong Lee ${ }^{\mathrm{c}}$ \\ ${ }^{a}$ Center for Environmental Remediation, Institute of Geographic Sciences and Natural Resources Research, Chinese Academy of \\ Sciences, Beijing 100101, PR China \\ ${ }^{\mathrm{b}}$ Graduate School of the Chinese Academy of Sciences, Beijing 100039, PR China \\ ${ }^{\mathrm{c}}$ Department of Chemical Engineering, National Taiwan University, Taipei, Taiwan
}

Received 7 November 2007; received in revised form 19 February 2008; accepted 20 February 2008

Available online 8 April 2008

\begin{abstract}
In this study, a settlement measurement device was used to track the settlement of different layers in composting piles, and time courses of settlement velocity, bulk density distribution, and effective bulk density were investigated. Settlement is divided into two stages: the physical compressive settlement and the mass loss settlement. At the end of the former stage, bulk density $\left(\rho^{\prime}\right)$ and pile height (h) follow $\rho^{\prime}=A h^{B}$, where $A$ is a fitting parameter for the initial bulk density of the composting material, and $B$ is the compression parameter. The physical compressibilities of composting mixtures are night-soil sludge and garden refuse (1:1) $>$ sewage sludge and cornstalks $(5: 4)>$ night-soil sludge and garden refuse $(2: 3)>$ sewage sludge and bark (1:1). Adding the proportion of bulking agent in the proper extent effectively retarded composting settlement. Bark exhibits a better supporting capability than cornstalk does as a bulking agent.
\end{abstract}

(C) 2008 Elsevier Ltd. All rights reserved.

Keywords: Bulk density; Composting; Settlement; Sludge; Volume reduction

\section{Introduction}

Composting is considered to be an important approach for treating a wide variety of organic solid wastes. However, plenty of factors, such as moisture content, oxygen supply and biodegradability of the composting materials, can directly affect composting process. Other factor like pile settlement can also indirectly hinder the successful composting. Pile settlement starts as soon as a composting pile is built, which leads to a reduction in the local porosity and permeability. Such an occurrence can significantly affect the efficiency of oxygen supply, water evaporation and heat ventilation rates in a composting pile (Haug, 1993; McCartney and Chen, 2001; Barrington et al., 2003; Chang and Veeken, 2004). Pile settlement was com-

\footnotetext{
* Corresponding author. Tel.: +8610 64889080; fax: +86 1064889303. E-mail address: chentb@igsnrr.ac.cn (T.-B. Chen).
}

posed of two stages. The first stage was the physical compressive settlement (PCS) that occurred in the first few days of composting, during which the bulk density distribution formed in the composting piles; the second stage was the mass loss settlement (MLS) attributable to organic matter degradation and moisture evaporation (Van Lier et al., 1994; Van Ginkel et al., 1999; Bowders et al., 2000). Moreover, the changes in mechanical properties of the composting materials at increased temperatures should contribute to pile settlement throughout the test (Chang and Veeken, 2004).

Plenty of investigations indicated that the significant reduction in material mass and volume occurred during composting (Lopez-Real, 1990; Van Lier et al., 1994; Larney et al., 2000; Brodie et al., 2000; Veeken et al., 2002). The reduction in material mass and volume were considered to be the key parameters for the design and management of a composting facility (Breitenbeck and 
Schellinger, 2004). During the commonly adopted forcedaeration static pile composting process, settlement has been noted together with a reduction in quantity material (Van Lier et al., 1994; Van Ginkel et al., 1999).

As shown in Table 1, significant differences in the reduction ratios were found in the different composting, such as natural ventilation static pile composting, mechanical turning windrow composting and forced-aeration static pile composting. The mechanical turning windrow composting had the highest reduction (Van Ginkel et al., 1999; Brodie et al., 2000; Breitenbeck and Schellinger, 2004), with a maximum reduction ratio of $83 \%$ reported by Larney et al. (2000). Prolonging the composting time led to an increase in the reduction ratios (Larney et al., 2000; Brodie et al., 2000; Breitenbeck and Schellinger, 2004). A combination composting method, such as forced-aeration windrow composting with turning, proved to be an effective approach for an increase in reduction (Lopez-Real, 1990).

Settlement velocities and distributions of bulk density in a compost pile present important process parameters that need close monitoring in composting. This work monitored the settlements of different layers, and then calculated the settlement velocities, pile bulk density distributions and reduction ratios of materials in composting tests.

\section{Methods}

\subsection{Test materials}

Sewage sludge and night-soil sludge were obtained from the Gaobeidian Wastewater Treatment Plant in Beijing and the Luohu District septic tank in Shenzhen, China, respectively. Three amendments were used: crushed tree bark (4$7 \mathrm{~cm}$ in size), cornstalk (3-6 cm in size) and garden refuse (3-5 $\mathrm{cm}$ in size). Garden refuse comprised branches and leaves. The physical and chemical properties of the testing materials are described in Table 2.

\subsection{Composting experiment}

The forced-aeration static pile composting systems were adopted, and the composting processes were monitored and controlled by the temperature sensors with a CTB automatic system and Compsoft ${ }^{\circledR}$ Version 2.0 software (Chen et al., 2001a,b,c). Table 3 lists the initial conditions of the four composting trials. Treatments 1 and 2 were composted in composting pools $(1.5 \mathrm{~m}$ length $\times 1.2 \mathrm{~m}$ width $\times 1.7 \mathrm{~m}$ height) with composting period of 24 and $22 \mathrm{~d}$, respectively. The pile heights for Treatments 1 and

Table 1

Volume and mass reduction of the test materials during different composting processes

\begin{tabular}{|c|c|c|c|c|c|c|}
\hline Composting process & Composting material & $\begin{array}{l}\text { Composting } \\
\text { time }(d)\end{array}$ & $\begin{array}{l}\text { Volume reduction } \\
(\% \text { of initial) }\end{array}$ & $\begin{array}{l}\text { Volume reduction } \\
\text { ratio per day } \\
(\% \text { of initial })\end{array}$ & $\begin{array}{l}\text { Mass reduction } \\
(\% \text { of initial })\end{array}$ & Reference \\
\hline $\begin{array}{l}\text { Forced-aeration static pile } \\
\text { composting }\end{array}$ & $\begin{array}{l}\text { Horse manure, broiler } \\
\text { chicken manure, } \\
\text { wheat straw }\end{array}$ & 7 & 8.1 & 1.16 & 38.3 & $\begin{array}{l}\text { Van Lier et al. } \\
\text { (1994) }\end{array}$ \\
\hline \multirow{2}{*}{$\begin{array}{l}\text { Mechanical turning } \\
\text { windrow composting }\end{array}$} & \multirow{2}{*}{$\begin{array}{l}\text { Chicken manure, } \\
\text { wheat straw }\end{array}$} & $7(0-7 d)$ & 31 & 4.43 & - & \multirow{2}{*}{$\begin{array}{l}\text { Van Ginkel et al. } \\
\text { (1999) }\end{array}$} \\
\hline & & $7(21-28 d)$ & 16 & 2.29 & - & \\
\hline $\begin{array}{l}\text { Forced-aeration windrow } \\
\text { composting with turning }\end{array}$ & Seaweed, straw & 28 & 77 & 2.75 & 50 & Lopez-Real (1990) \\
\hline \multirow[t]{4}{*}{$\begin{array}{l}\text { Mechanical turning } \\
\text { windrow composting }\end{array}$} & $\begin{array}{l}\text { Bagasse (rinds of } \\
\text { sugarcane), spoiled } \\
\text { corn silage }\end{array}$ & 100 & 52.2 & 0.52 & 15.2 & \multirow[t]{4}{*}{$\begin{array}{l}\text { Breitenbeck and } \\
\text { Schellinger (2004) }\end{array}$} \\
\hline & $\begin{array}{l}\text { Cotton gin trash, bagasse, } \\
\text { rice hulls }\end{array}$ & 100 & 53.5 & 0.54 & 31.4 & \\
\hline & $\begin{array}{l}\text { Grass hay, spoiled corn } \\
\text { silage }\end{array}$ & 100 & 57.9 & 0.58 & 18.2 & \\
\hline & $\begin{array}{l}\text { Wood chips, municipal } \\
\text { biosolids }\end{array}$ & 100 & 18.6 & 0.19 & 11.5 & \\
\hline \multirow{3}{*}{$\begin{array}{l}\text { Passive aeration static pile } \\
\text { composting }\end{array}$} & \multirow{3}{*}{$\begin{array}{l}\text { Straw-rich manure, } \\
\text { wheat straw }\end{array}$} & 46 & 9.7 & 0.21 & 5.1 & \multirow{3}{*}{$\begin{array}{l}\text { Veeken et al. } \\
(2002)\end{array}$} \\
\hline & & 98 & 30.8 & 0.31 & 33.1 & \\
\hline & & 137 & 27.4 & 0.74 & 41.7 & \\
\hline $\begin{array}{l}\text { Natural ventilation } \\
\text { static pile composting }\end{array}$ & $\begin{array}{l}\text { Poultry litter, wood } \\
\text { chips, sawdust }\end{array}$ & 300 & 33 & 0.11 & - & $\begin{array}{l}\text { Brodie et al. } \\
(2000)\end{array}$ \\
\hline $\begin{array}{l}\text { Mechanical turning } \\
\text { windrow composting }\end{array}$ & $\begin{array}{l}\text { Poultry litter, wood } \\
\text { chips, sawdust }\end{array}$ & 150 & 41 & 0.27 & - & \\
\hline \multirow[t]{2}{*}{$\begin{array}{l}\text { Mechanical turning } \\
\text { windrow composting }\end{array}$} & \multirow[t]{2}{*}{$\begin{array}{l}\text { Cattle manure, } \\
\text { barley straw }\end{array}$} & $\begin{array}{l}188 \text { (in } \\
\text { summer) }\end{array}$ & 83 & 0.44 & - & \multirow[t]{4}{*}{$\begin{array}{l}\text { Larney et al. } \\
(2000)\end{array}$} \\
\hline & & 300 (in winter) & 64 & 0.21 & - & \\
\hline \multirow[t]{2}{*}{$\begin{array}{l}\text { Passive aeration static pile } \\
\text { composting }\end{array}$} & \multirow[t]{2}{*}{$\begin{array}{l}\text { Cattle manure, } \\
\text { barley straw }\end{array}$} & $\begin{array}{l}188 \text { (in } \\
\text { summer) }\end{array}$ & 73 & 0.39 & - & \\
\hline & & 300 (in winter) & 53 & 0.18 & - & \\
\hline
\end{tabular}


Table 2

Physical and chemical properties of tested materials (standard deviations in brackets)

\begin{tabular}{|c|c|c|c|c|c|c|c|c|}
\hline \multirow{2}{*}{$\begin{array}{l}\text { Material } \\
\text { Sewage sludge }\end{array}$} & \multicolumn{2}{|c|}{$\begin{array}{l}\text { Water content } \\
\left(\%, \text { w.b. }{ }^{a}\right)\end{array}$} & \multicolumn{2}{|c|}{$\begin{array}{l}\text { Bulk density } \\
\left(\mathrm{kg} / \mathrm{m}^{3} \text {, w.b. }{ }^{\mathrm{a}}\right)\end{array}$} & \multicolumn{2}{|c|}{$\begin{array}{l}\text { Volatile solid } \\
\left(\%, \text { d.b. }^{\mathrm{b}}\right)\end{array}$} & \multirow{2}{*}{$\begin{array}{l}\text { Total N } \\
\left(\%, \text { d.b. }{ }^{\mathrm{b}}\right)\end{array}$} & \multirow{2}{*}{$\begin{array}{l}\text { Total P } \\
\left(\%, \text { d.b. }^{\mathrm{b}}\right)\end{array}$} \\
\hline & 82.0 & $(0.21)$ & 990.7 & $(31.7)$ & 54.2 & $(0.71)$ & & \\
\hline $\begin{array}{l}\text { Night-soil } \\
\text { sludge }\end{array}$ & 76.0 & $(0.47)$ & 801.5 & $(48.2)$ & 75.0 & $(0.54)$ & 2.53 & 1.73 \\
\hline Bark & 30.0 & $(0.52)$ & 185.7 & $(57.3)$ & 89.2 & $(0.27)$ & 0.64 & 0.27 \\
\hline Cornstalk & 22.2 & $(1.37)$ & 49.8 & $(13.7)$ & 90.3 & $(0.89)$ & 0.95 & 0.15 \\
\hline Garden refuse & 32.0 & $(1.52)$ & 220.2 & $(47.1)$ & 91.8 & $(0.64)$ & 0.75 & 0.90 \\
\hline
\end{tabular}

${ }^{\text {a }}$ w.b. refers to a wet basis.

b d.b. refers to a dry basis.

Table 3

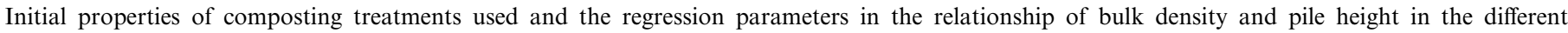
composting piles (standard deviations in brackets)

\begin{tabular}{|c|c|c|c|c|c|c|c|c|c|c|}
\hline \multirow[t]{2}{*}{ Treatment } & \multirow[t]{2}{*}{$\begin{array}{l}\text { Composting materials } \\
\text { and proportion }(\mathrm{V} / \mathrm{V})^{\mathrm{a}}\end{array}$} & \multirow{2}{*}{\multicolumn{2}{|c|}{$\begin{array}{l}\text { Water } \\
\text { content } \\
\left(\%, \text { w.b. }{ }^{b}\right)\end{array}$}} & \multirow{2}{*}{\multicolumn{2}{|c|}{$\begin{array}{l}\text { Initial bulk } \\
\text { density } \\
\left(\mathrm{kg} / \mathrm{m}^{3}, \mathrm{w} \cdot \mathrm{b} .^{\mathrm{b}}\right)\end{array}$}} & \multicolumn{3}{|c|}{$\begin{array}{l}\text { Regression parameters } \\
\left(\rho^{\prime}=\mathrm{A} h^{\mathrm{B}}\right)\end{array}$} & \multirow[t]{2}{*}{$\begin{array}{l}\text { Function of bulk } \\
\text { density distribution }\end{array}$} & \multirow[t]{2}{*}{$\begin{array}{l}\text { Effective bulk } \\
\text { density }\left(\mathrm{kg} / \mathrm{m}^{3}\right)\end{array}$} \\
\hline & & & & & & $A$ & $B$ & $R^{2}$ & & \\
\hline 1 & Sewage sludge: bark $=1: 1$ & 73.2 & $(0.26)$ & 789 & $(76.3)$ & 926.3 & 0.071 & 0.97 & $\rho^{\prime}=926.3 h^{0.071}$ & 885.8 \\
\hline 2 & Sewage sludge: cornstalk $=4: 5$ & 70.4 & $(0.18)$ & 627 & $(55.1)$ & 813.1 & 0.112 & 0.95 & $\rho^{\prime}=813.1 h^{0.112}$ & 759.3 \\
\hline 3 & Night-soil sludge:garden refuse $=2: 3$ & 70.1 & $(0.21)$ & 429 & $(45.3)$ & 482.1 & 0.095 & 0.92 & $\rho^{\prime}=482.1 h^{0.095}$ & 502.2 \\
\hline 4 & Night-soil sludge:garden refuse $=1: 1$ & 72.8 & $(0.15)$ & 475 & $(49.7)$ & 558.0 & 0.127 & 0.94 & $\rho^{\prime}=558.0 h^{0.127}$ & 590.4 \\
\hline
\end{tabular}

${ }^{a} \mathrm{~V} / \mathrm{V}$ refers to the volume proportion.

b w.b. refers to a wet basis.

2 were $1.4 \mathrm{~m}$. The temperature sensors were set 0.6 and $0.8 \mathrm{~m}$ from the bottom at the central beams of each composting pile. The gas distribution plates with $1.5 \times 3 \mathrm{~cm}^{2}$ holes were fixed above the air chamber $(0.2 \mathrm{~m}$ height $)$ which supported the composting materials and allowed inflow of ambient air in the compost bed. The aeration strategies for Treatments 1 and 2 were identical. Treatments 3 and 4 were composted in composting pools ( $2.5 \mathrm{~m}$ length $\times 1.5 \mathrm{~m}$ width $\times 5.3 \mathrm{~m}$ height $)$ with composting periods of 25 and $12 \mathrm{~d}$, respectively. The pile heights for Treatments 3 and 4 were $4.0 \mathrm{~m}$. The composting temperatures of Treatments 3 and 4 were monitored at heights of 1.5 and $2.5 \mathrm{~m}$, respectively. Three-layer aeration systems were designed for both Treatments 3 and 4 . The three-layer forced-aeration tubes were set horizontally at the height of $1.0,2.0$ and $3.0 \mathrm{~m}$, respectively. Each layer had three parallel tubes with pores $(5 \mathrm{~mm}$ in diameter) in the purpose of uniform gas distribution.

\subsection{Settlement measurement}

A settlement measurement device tracked settlements of different layers in a composting pile with a precision of $\pm 1 \mathrm{~mm}$ (Yue et al., 2007). The settlement tracking device comprised settlement plates $\left(0.3 \times 0.3 \mathrm{~m}^{2}\right.$ in area and $0.01 \mathrm{~m}$ in thickness), stainless steel wires and tubes, shelves with reference marks, and the cable-displacement measurement apparatus. In order not to stop the moisture, heat and air exchange in the composting pile, the $60 \%$ area of settlement plates were uniformly drilled with pores $(5 \mathrm{~mm}$ in diameter). Settlement plates were horizontally installed for layers at prescribed heights, with wires linked to each plate's center. Tubes used for minimizing friction between wires and composting materials were then fastened to the fixed shelves with reference marks. The wires were connected to the cable-displacement measurement apparatus, which were also fixed to the shelves, to record in situ the pile settlements. The prescribed layer-intervals were $0.2 \mathrm{~m}$ for Treatments 1 and $2,0.5 \mathrm{~m}$ for Treatments 3 and 4 . The uninterrupted settlement of a layer might affect the decision for the height of a plate's installation. To ensure the same initial intervals for each layer, each settlement plate height is determined by the previous plate.

\subsection{Data interpretation}

\subsubsection{Bulk density and FAS distribution}

The composting material of the target layer was compacted under self-weight compressive stress. The compressed distance $(\Delta h)$ of the layer was determined by measuring the settlement of the plates at the top and bottom of this layer. Following the determination of initial unloaded bulk densities $\left(\rho_{0}\right)$, the bulk density of $\left(\rho^{\prime}\right)$ each layer can be calculated. The relationship is

$S H_{0} \rho_{0}=S\left(H_{0}-\Delta h\right) \rho^{\prime}$

where $S$ is the base area $\left(\mathrm{m}^{2}\right) ; H_{0}$ is the initial height of each layer $(\mathrm{m})$, which was $0.2 \mathrm{~m}$ for Treatments 1 and 2 , and $0.5 \mathrm{~m}$ for Treatments 3 and $4 ; \Delta h$ is the compressed distance $(\mathrm{m}) ; \rho_{0}$ is the initial unloaded bulk density $\left(\mathrm{kg} / \mathrm{m}^{3}\right)$; 
$\rho^{\prime}$ is the bulk density after compression $\left(\mathrm{kg} / \mathrm{m}^{3}\right) . \rho^{\prime}$ can be expressed as

$\rho^{\prime}=H_{0} \rho_{0} /\left(H_{0}-\Delta h\right)$

Bulk density distribution functions were obtained by fitting the data of bulk densities and pile heights. Through laboratory-scale simulation, Schaub-Szabo and Leonard (1999) presented the function of bulk density distribution as a function of pile heights as follow,

$\rho^{\prime}=A h^{B}$

where the constant $\mathrm{A}$ is a fitting parameter depending on the initial bulk density of the materials $\left(\mathrm{kg} / \mathrm{m}^{3}\right)$, and the exponent $\mathrm{B}$ is an indicator of the physical compressibility of the materials in dimensionless form.

Providing that water content and particle density of composting materials were determined, the FAS (\%) distribution function can be estimated using Eq. (4) (Agnew et al., 2003).

$$
\text { FAS }=100-\rho^{\prime}(100-\eta) / \rho_{\text {solid }}-\rho^{\prime} \eta / \rho_{\text {water }}
$$

where FAS is the free air space (\%); $\eta$ is the wet basis moisture content $(\%) ; \rho_{\text {solid }}$ is the particle density $\left(\mathrm{kg} / \mathrm{m}^{3}\right) ; \rho_{\text {water }}$ is the density of water $\left(1000 \mathrm{~kg} / \mathrm{m}^{3}\right)$. At the initial stage of the composting process, water content and particle density can be considered as constants.

\subsubsection{Effective bulk density}

The effective bulk density was defined as

$\rho_{\text {eff }}=\frac{1}{h} \int_{0}^{h} \rho^{\prime} \mathrm{d} h=\frac{1}{h} \int_{0}^{h} A h^{B} \mathrm{~d} h$

\subsection{Physicochemical characterization}

The wet bulk density was determined by the bucket drop method (Larney et al., 2000; Agnew and Leonard, 2003; Breitenbeck and Schellinger, 2004). An aluminum pail with a volume of $0.064 \mathrm{~m}^{3}$ were filled $1 / 3$ full with composting materials, dropped on the ground 10 times, filled with $1 / 3$ more materials and dropped 10 times, filled to the top and dropped 10 times, filled to the top again, level off using a straight edge in a sawing motion, then weighed using a balance to provide the weight of the materials. The initial unloaded bulk density was also estimated as the mass of composting materials required to fill the $0.064 \mathrm{~m}^{3}$ aluminum pail. However, no drop or press operation has been done during the sample-filling process except slight shaking. Sub-samples were collected for the moisture determination. About $20 \mathrm{~g}$ samples were oven-dried at $70{ }^{\circ} \mathrm{C}$ to a constant weight and water content was expressed on a wet weight basis (weight of water/wet weight of sample). About $5 \mathrm{~g}$ oven-dried samples were placed in $50 \mathrm{~mL}$ crucibles, combusted in a muffle furnace $\left(550 \pm 50{ }^{\circ} \mathrm{C}, 4 \mathrm{~h}\right)$, cooled in a desiccator, and weighed for the volatile solid (VS) determination.
Total nitrogen (TN) was estimated by Kjeldahl's method in which both organic nitrogen and ammoniacal nitrogen were converted to ammonium in the presence of concentrated $\mathrm{H}_{2} \mathrm{SO}_{4}$ and cupric sulphate $\left(\mathrm{CuSO}_{4}\right)$ catalyst. Then, ammonia was distilled from an alkaline medium and absorbed in boric acid. The distilled ammonia was determined by titration with a standard mineral acid. Total phosphorus (TP) was determined using the persulphate digestion method in which all the species of phosphorus in a sample were converted to orthophosphates. The samples were then filtered and the phosphorus was measured using the ascorbic acid method (Ndegwa and Zhu, 2003).

\section{Results and discussion}

\subsection{Composting temperature}

The composting temperatures for four trials (Fig. 1) all achieved the required $55^{\circ} \mathrm{C}$ for more than three consecutive days (USEPA, 1989; Li et al., 2008). The maximum temperatures for Treatments 1, 3 and 4 exceeded $70{ }^{\circ} \mathrm{C}$. The temperature rise for Treatment 3 occurred earlier than for other piles (Fig. 1c). Treatment 1 had the longest sterilization time over $55^{\circ} \mathrm{C}$ amongst the four Treatments, indicating that it was facilitated to achieve the pasteurization temperature threshold (Fig. 1a).

\subsection{Pile settlement}

Pile settlement was distinctly composed of two stages (Fig. 2). The first stage was the PCS that occurred in the first few days of composting; the second stage was the MLS attributable to organic matter degradation and moisture evaporation.

Under the same pile height, Treatment 1 , with bark as the bulking agent, had a less PCS than Treatment 2, with cornstalk as the bulking agent (Fig. 2a and b). Therefore bark better supported the pile than cornstalk did, which is in agreement with the results of SchaubSzabo and Leonard (1999) and McCartney and Chen (2001). Especially, when cornstalk was deposited in wet and high-temperature surroundings, the supporting role of cornstalk decreased dramatically (Barrington et al., 2003). On the other hand, Treatment 3 settled less than Treatment 4 since the former had a higher volume proportion of garden refuse (Fig. 2c and d). It is implied that increasing the proportion of bulking agent in the proper extent effectively reduces PCS.

\subsection{Bulk density distributions of piles}

Settlement velocity, defined as the daily compressive deformation of a pile, represents the physical compressibilities of the tested piles. The settlement velocities of pile surface and composting time were well fitted with exponential 

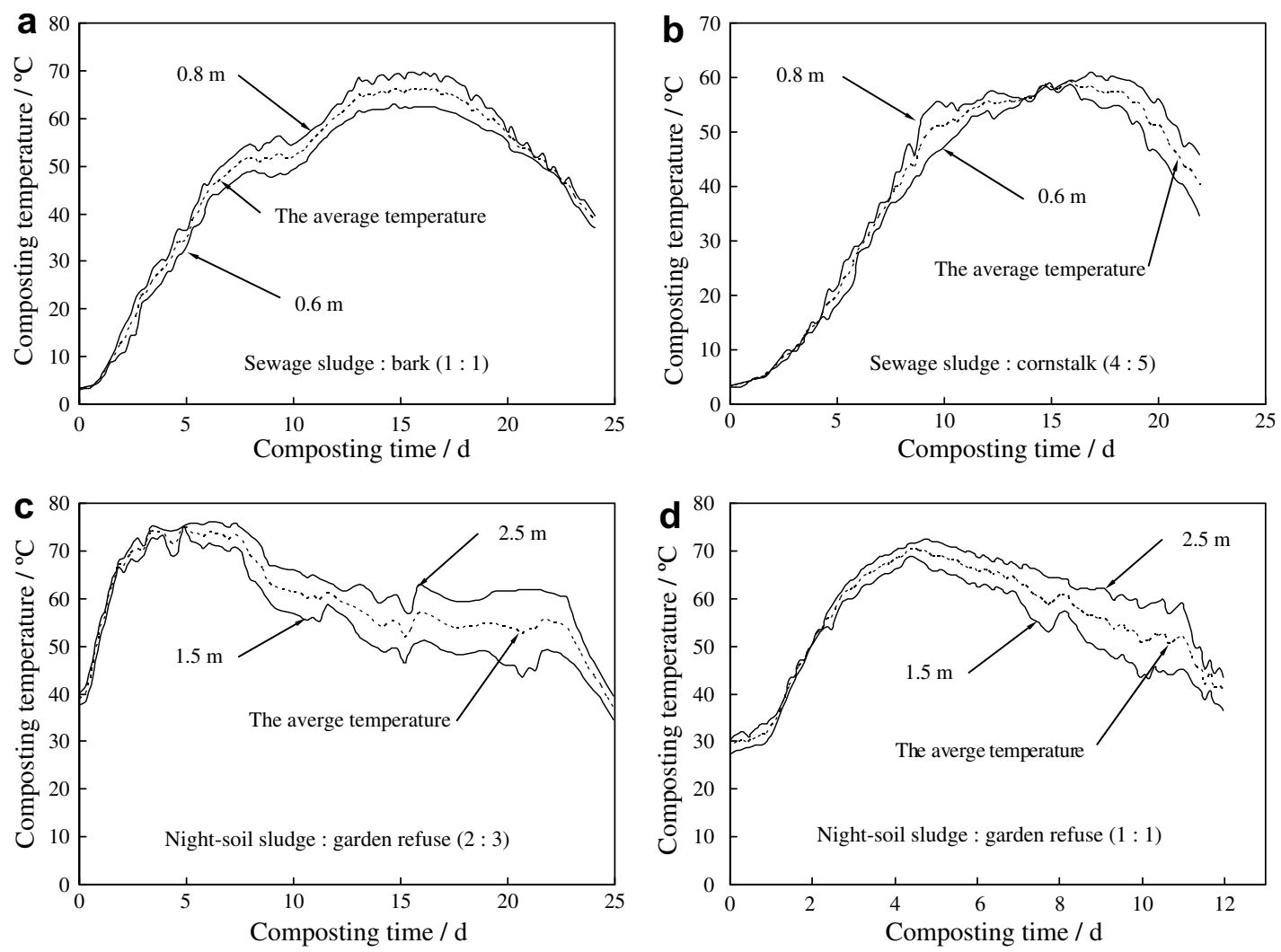

Fig. 1. Temperature variations for the four Treatments in the composting process. The composting temperature variations for each Treatment were comprised of the upper and under-layer temperatures measured by temperature sensors at the set heights $(0.6$ and $0.8 \mathrm{~m}$ for Treatments 1 and $2,1.5$ and $2.5 \mathrm{~m}$ for Treatments 3 and 4, respectively). The average value of the upper and under-layer temperatures were used to estimate the sterilization time.

functions (Fig. 3). Following a rapid settlement, the settlement velocities remained almost unchangeable in the remaining process.

The PCS stages for Treatments 1 and 2 were completed approximately on day 2. Conversely, the durations of PCS for Treatments 3 and 4 were $5-7 \mathrm{~d}$, probably owing to the blockages in three-layer gas distribution tubes or/and the changing physical properties of compost materials at increased temperatures. Sixth day was taken as the point of differentiation between PCS and MLS stages for Treatments 3 and 4 (Fig. 3c and d).

As shown in Fig. 3a and b, the maximums of settlement velocity in the PCS stage for Treatments 1 and 2 are -0.383 and $-0.633 \mathrm{~m} / \mathrm{d}$, respectively. In the MLS stage, the means of settlement velocity for Treatments 1 and 2 are $-11.1 \pm 2.4 \times 10^{-3}$ and $-10.4 \pm 2.4 \times 10^{-3} \mathrm{~m} / \mathrm{d}$, respectively. For Treatments 3 and 4, the maximums of settlement velocity in the PCS stage are -0.207 and $-0.277 \mathrm{~m} /$ $\mathrm{d}$, and the mean of settlement velocities in the MLS stage are $-7.6 \pm 4.8 \times 10^{-3}$ and $-8.8 \pm 1.7 \times 10^{-3} \mathrm{~m} / \mathrm{d}$, respectively (Fig. $3 \mathrm{c}$ and d).

The height distributions of the settlement plates were measured by the settlement measurement device, then, the compressed distances between neighboring plates were calculated. The local bulk densities can be estimated by combining the initial unloaded bulk densities and com- pressed distances. Finally, the bulk density distributions as a function of pile heights were obtained by fitting the experimental data with Eq. (3). The best-fit parameters list in Table 3, and the regressed results and experimental data are shown in Fig. 4.

Parameters A and B for Treatments 1 and 2 are 926 and $813 \mathrm{~kg} \mathrm{~m}^{-3}$, and 0.071 and 0.112 , respectively. The higher parameter A for Treatment 1 than for Treatment 2 reveals a higher initial bulk density for the former. The larger parameter B for Treatment 2 than for Treatment 1 indicates the bark is better than cornstalk as a bulking material for sewage sludge composting.

Parameters A and B for Treatments 3 and 4 are 482 and $558 \mathrm{~kg} \mathrm{~m}^{-3}$, and 0.095 and 0.127 , respectively. The higher parameter A for Treatment 4 than for Treatment 3 reveals a higher initial bulk density for the former. The larger parameter B for Treatment 4 than for Treatment 3 indicates the increased fraction of night-soil sludge reduced the mechanical strength of the pile.

A comparison of the values of exponent $\mathrm{B}$ for the four trials indicates the most compressible material was Treatment 4 followed by Treatments 2, 3 and 1 (Fig. 4). The order of the physical incompressibilities of the four mixtures was: sewage sludge and bark (1:1)> night-soil sludge and garden refuse $(2: 3)>$ sewage sludge and cornstalks $(5: 4)>$ night-soil sludge and garden refuse (1:1). 

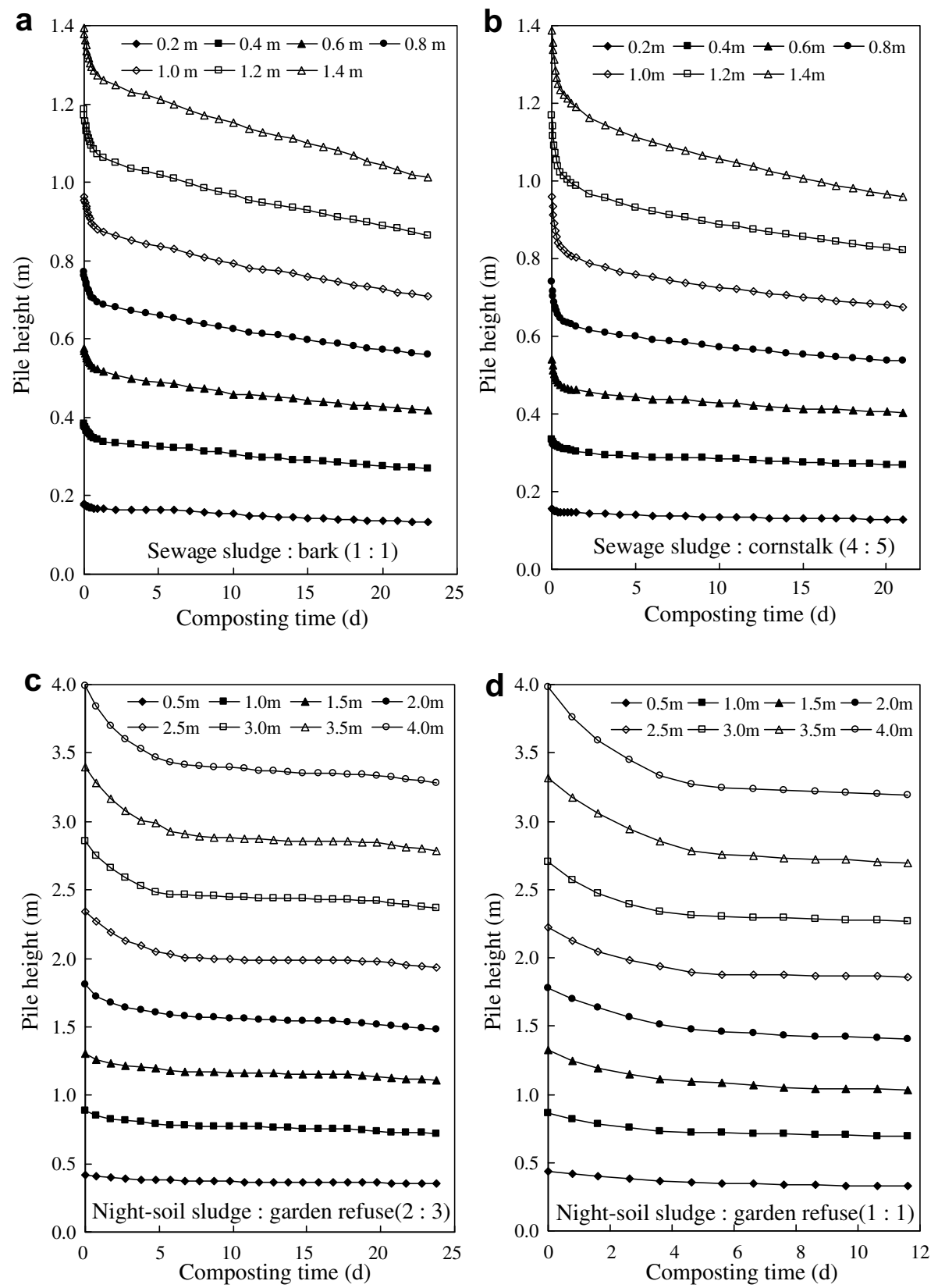

Fig. 2. Settlement variations for the different layers in the composting process, tracked by the settlement measurement device. Four different test materials were used: Treatment 1 (sewage sludge:bark $=1: 1, \mathrm{~V} / \mathrm{V}$ ), Treatment 2 (sewage sludge:cornstalk $=4: 5$ ), Treatment 3 (night-soil sludge:garden refuse $=2: 3$ ) and Treatment 4 (night-soil sludge:garden refuse $=1: 1$ ). The pile height of Treatments 1 and 2 were $1.4 \mathrm{~m}$, and that of Treatments 3 and 4 were $4.0 \mathrm{~m}$.

\subsection{Effective bulk density}

With the bulk density distribution in Table 3 , the effective bulk densities of Treatments $1-4$ are evaluated using Eq. (5) as $886,759,502$ and $590 \mathrm{~kg} \mathrm{~m}^{-3}$, respectively. The effective bulk density presents an adequate index of the bulk density of the piles.

\subsection{Reduction ratio}

The settlement heights in PCS and MLS for the four tested piles are listed in Table 4. The settlement heights in PCS for Treatments 1 and 2 were 0.156 and $0.238 \mathrm{~m}$, respectively, accounting for volume reductions of $11.1 \%$ and $17.0 \%$ to the initial pile height. Aeration hindrance owing to pile structure collapse should therefore be more serious for Treatment 2 than for Treatment 1, hence leading to poorer subsequent organic degradation for the former. This interpretation is confirmed by the higher peak temperature for Treatment 1 (Fig. 1) and the corresponding greater volume reduction ratio owing to mass loss (16.9\% compared with $14.4 \%$ ).

The PCS of Treatments 3 and 4 were 0.571 and $0.755 \mathrm{~m}$, accounting for volume reductions of $14.3 \%$ and $18.9 \%$ to 

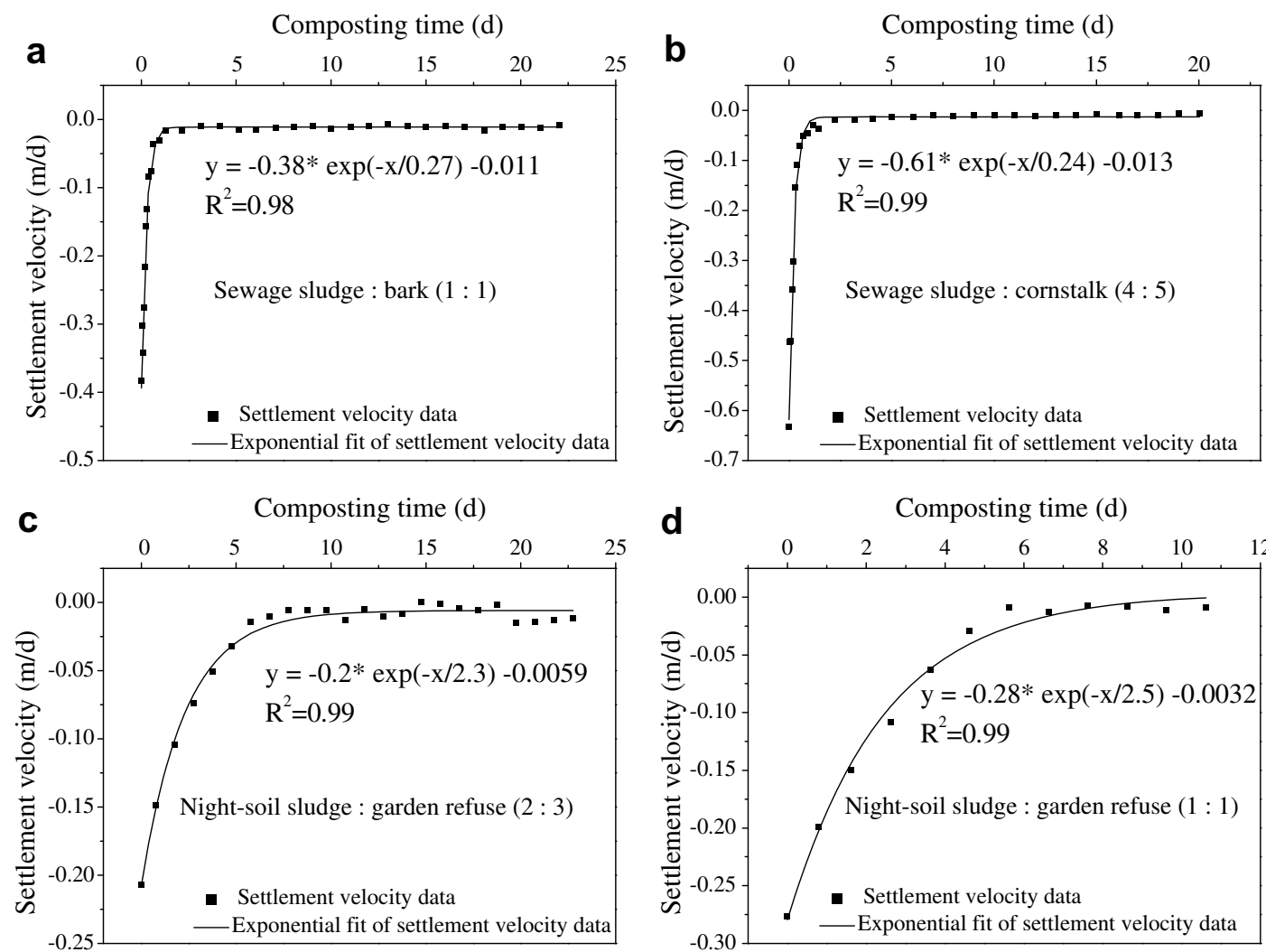

Fig. 3. Surface settlement velocity variations of the composting piles. The data are the differential coefficient of settlement to composting time. The relationships between settlement velocities and composting times were fitted with an exponential function, having a high $R^{2}$.

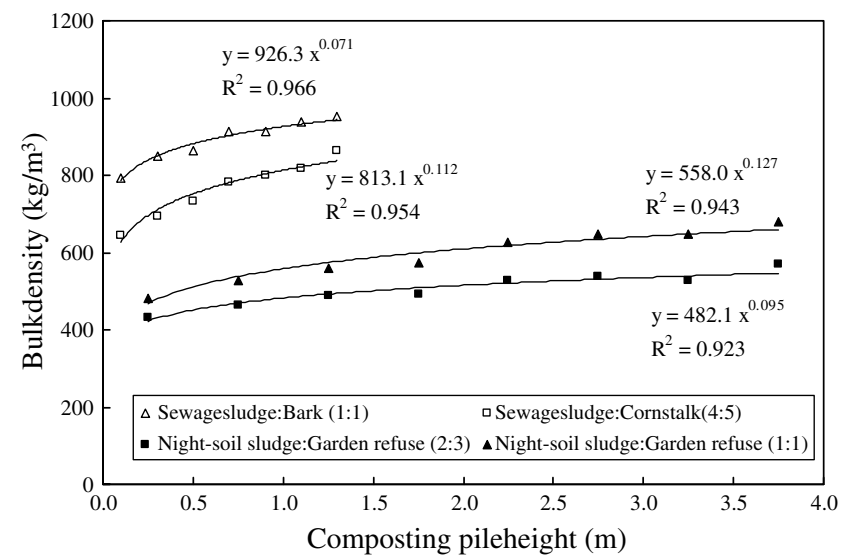

Fig. 4. Profile of bulk density distributions for the four composting piles. The bulk density of each layer in the piles was estimated by Eq. (2). The relationships between bulk density and pile height were fitted well with Eq. (3) presented by Schaub-Szabo and Leonard (1999). the initial pile volume. The MLSs were 0.145 and $0.057 \mathrm{~m}$, and the volume reduction ratios $3.6 \%$ and $1.4 \%$, respectively. The difference in the volume reduction ratios in mass loss between Treatments 3 and 4 was mainly due to the different composting times ( $25 \mathrm{~d}$ compared with $12 \mathrm{~d}$ ). The PCS might affect the temperature rising rate, which is supported by the composting temperature data (Fig. 1). Under uniform aeration conditions, Treatment 3 had a larger temperature rising rate than Treatment 4, which was crucial to the outcome of the composting, especially in an unusual environment, such as cold weather.

In a comparison of volume reduction ratios of the four trials due to mass loss, the ratios for Treatments 1 and 2 were significantly higher than for Treatments 3 and 4, which might be associated with the specific surface areas of the piles. The specific surface areas of Treatments 1 and 2 were higher than those of Treatments 3 and 4 , and

Table 4

Settlements and reduction ratios in different settlement stages during the composting process

\begin{tabular}{|c|c|c|c|c|c|c|c|c|}
\hline \multirow[t]{2}{*}{ Treatment } & \multirow{2}{*}{$\begin{array}{l}\text { Composting } \\
\text { time }(d)\end{array}$} & \multicolumn{2}{|l|}{ Stage 1} & \multicolumn{2}{|l|}{ Stage 2} & \multicolumn{3}{|c|}{ Whole process } \\
\hline & & $\begin{array}{l}\text { Settlement } \\
(\mathrm{m})\end{array}$ & $\begin{array}{l}\text { Volume reduction } \\
\text { ratio }(\%)\end{array}$ & $\begin{array}{l}\text { Settlement } \\
(\mathrm{m})\end{array}$ & $\begin{array}{l}\text { Volume reduction } \\
\text { ratio }(\%)\end{array}$ & $\begin{array}{l}\text { Settlement } \\
(\mathrm{m})\end{array}$ & $\begin{array}{l}\text { Volume reduction } \\
\text { ratio }(\%)\end{array}$ & $\begin{array}{l}\text { Volume reduction } \\
\text { ratio per day }(\%)\end{array}$ \\
\hline 1 & 24 & 0.156 & 11.1 & 0.236 & 16.9 & 0.392 & 28.0 & 1.17 \\
\hline 3 & 25 & 0.571 & 14.3 & 0.145 & 3.6 & 0.716 & 17.9 & 0.72 \\
\hline 4 & 12 & 0.755 & 18.9 & 0.057 & 1.4 & 0.812 & 20.3 & 1.69 \\
\hline
\end{tabular}


thus had a reduction advantage with greater water evaporation, mass and heat exchange to the surroundings.

Compared with mechanical turning windrow composting, forced-aeration static pile composting had lower reduction (Van Lier et al., 1994; Veeken et al., 2002). However, forced-aeration static pile composting can yield a higher daily reduction in volume during the whole process (Tables 1 and 4), which is attributed to the shorter composting time and more rapid degradation of organic matter.

In the four investigated Treatments, the daily reductions in volume were equivalent to that of the forced-aeration static pile composting used by Van Lier et al. (1994), and significantly higher than that of the mechanical turning windrow composting presented by Brodie et al. (2000), Larney et al. (2000) and Breitenbeck and Schellinger (2004).

\section{Conclusions}

Layer settlement velocities and distributions of bulk density in four forced-aeration static composting piles were measured using a settlement tracking device proposed by Yue et al. (2007) with a precision of $1 \mathrm{~mm}$.

All composting pile settlements are composed of two stages: the PCS and MLS stages. Higher piles lead to the more PCS. Approaches such as choosing the proper bulking materials or/and increasing the proportion of bulking agent in the proper extent effectively retarded composting settlement.

At the end of PCS, the relationships between bulk density and pile height correlated with the function $\rho^{\prime}=\mathrm{A} h^{\mathrm{B}}$. The best-fits of parameter B reveal the physical compressibilities, with night-soil sludge and garden refuse $(1: 1)>$ sewage sludge and cornstalks $(5: 4)>$ night-soil sludge and garden refuse (2:3) > sewage sludge and bark $(1: 1)$.

A high volume reduction in PCS will indirectly affect the temperature rising and the high-temperature lasting time, yield poor subsequent organic matter degradation in the composting pile.

Since the experiment has been done in middle-scale, more data in the laboratory-scale need to be collected in the further work. While the physical compressibilities of the various composting materials were more accurately determined through the laboratory simulation and justified in the middle-scale, the data will be more useful for designing the proper recipes, proportions and pile heights for the particular composting materials.

\section{Acknowledgements}

This research was funded by grants from the Natural Science Foundation of Beijing (Grant No. 8051003) and the National High Technology Research and Development Program of China (Grant No. 2006AA06Z384). We wish to thank Dr. Augustine Doronila for assistance in writing the article.

\section{References}

Agnew, J.M., Leonard, J.J., 2003. The physical properties of compost. Compost Science and Utilization 11, 238-264.

Agnew, J.M., Leonard, J.J., Feddes, J., Feng, Y., 2003. A modified air pycnometer for compost air volume and density determination. Canadian Biosystems Engineering 45, 27-35.

Barrington, S., Choinière, D., Trigui, M., Knight, W., 2003. Compost convective airflow under passive aeration. Bioresource Technology 86, 259-266.

Bowders, J.J., Bouazza, M., Loehr, E., Russell, M. 2000. Settlement of municipal solid waste landfill. In: Proceedings of Fourth Kansai International Geotechnical Forum, Creation of New Geo-Environment Kyoto, Japan, May 24-26, pp. 101-106.

Breitenbeck, G.A., Schellinger, D., 2004. Calculating the reduction in material mass and volume during composting. Compost Science and Utilization 12, 365-371.

Brodie, H.L., Carr, L.E., Condon, P., 2000. A comparison of static pile and turned windrow methods for poultry litter compost production. Compost Science and Utilization 8, 178-189.

Chang, Z.Z., Veeken, A., 2004. Effects of temperature on the structure of a compost bed-compress, porosity and permeability. Journal of Agroenvironmental Science 23, 791-795.

Chen, T.B., Gao, D., Huang, Q.F., 2001a. A complex temperature probe for compositing. Patent of PR China, No. 01120521. 0.

Chen, T.B., Gao, D., Huang, Q.F., 2001b. An automatic control apparatus in a composting system. Patent of PR China, No. 01120522. 9 .

Chen, T.B., Gao, D., Huang, Z.C., 2001c. Sludge composting automatic control software (V2.0). Copyright No. of PR China, No. SR0529.

Haug, R.T., 1993. The Practical Handbook of Compost Engineering. Lewis Publishers, Boca Raton, Florida, USA.

Larney, F.J., Olson, A.F., Carcamo, A.A., Chang, C., 2000. Physical changes during active and passive composting of beef feedlot manure in winter and summer. Bioresource Technology 75, 139-148.

Li, X.J., Zhang, R.H., Pang, Y.Z., 2008. Characteristics of dairy manure composting with rice straw. Bioresource Technology 99, 359-367.

Lopez-Real, J., 1990. Agro-industrial waste composting and its agricultural significance. Proceedings of the Fertilizer Society 293, 3-26.

McCartney, D., Chen, H., 2001. Using a biocell to measure effect of compressive settlement on free air space and microbial activity in windrow composting. Compost Science and Utilization 9, 285-302.

Ndegwa, P.M., Zhu, J., 2003. Sampling procedures for piggery slurry in deep pits for estimation of nutrient content. Biosystems Engineering 85 (2), 239-248

Schaub-Szabo, S.M., Leonard, J.J., 1999. Characterizing the bulk density of compost. Compost Science and Utilization 7, 15-24.

USEPA, 1989. Control of pathogens in municipal wastewater sludge for land application. Center for Environmental Research Information. Cincinnati, OH 45268. Environmental Regulations and Technology EPA/625/10-89/006, p. 71.

Van Ginkel, J.T., Raats, P.A.C., Van Haneghem, I.A., 1999. Bulk density and porosity distributions in a compost pile. Netherlands Journal of Agricultural Science 47, 105-121.

Van Lier, J.J.C., Van Ginkel, J.T., Straatsma, G., Gerrits, J.P.G., Van Griensven, L.J.L.D., 1994. Composting of mushroom substrate in a fermentation tunnel: compost parameters and a mathematical model. Netherlands Journal of Agricultural Science 42, 271-292.

Veeken, A., de Wilde, V., Hamelers, B., 2002. Passively aerated composting of straw-rich pig manure: effect of compost bed porosity. Compost Science and Utilization 10, 114-128.

Yue, B., Chen, T.B., Gao, D., Zheng, G.D., 2007. A method and device for settlement and bulk density measurement in the composting pile. Patent of PR China, No. 200710064596. 1. 